ISSN 2078-6441. Вісник Львівського університету. Серія географічна. 2013. Випуск 42. С. 306-310. Visnyk of the Lviv University. Series Geography. 2013. Issue 42. P. 306-310.

913:911.3

\author{
: \\ Мих йло утинський \\ ьвівський н ціон льний університет імені в н рнк, \\ вул. . орошенк, 41, 79000, м. ввів, кр їн
}

икон но історико-геогр фічне дослідження рекре ційно-інфр структурного потенці лу курорту сів у період його функціонув ння. підст ві н лізу процесів просторово-ч сової дин міки оцінено зн чення і місце оздоровниці в територі льній рекре ційній системі ьвівщини кінця -поч тку ст.

лючові слов : курорт, сів, гідротер певтичний з кл д, особливості розвитку, дин мік розвитку.

кту льність теми дослідження процесів просторово-ч сової дин міки лок льних курортних територі льних рекре ційних систем ( ) т історико-геогр фічної специфіки їхнього розвитку н був є особливої в ги в суч сних умов х дин мічної розбудови відпочинково-оздоровчих з кл дів н території ьвівської обл. омплексне вивчення "рецептів" успішного функціонув ння "м лих" водооздоровчих курортів ьвівщини минулих століть - продуктивний н прям до їхнього відродження у новому форм ті готельно-курортних комплексів зі ст нд рт ми SPA-оздоровлення ст.

н ліз ост нніх досліджень і публік цій свідчить, що дослідженню пит нь еволюції укр їнських курортів присвячено зн чну кількість н укових пр ць. еред укр їнських дослідників це коло пит нь н йгрунтовніше розроблене предст вник ми сімферопольської, київської, львівської і чернівецької н укових шкіл рекре ційної геогр фії [1]. егіон льні особливості розвитку курортів хідної кр їни з позицій суспільної геогр фії досліджув ли . узик, . ед шківськ , . уденко, . утинський, . тецюк т ін. роте комплексного історико-геогр фічного н лізу специфіки еволюції сівського курорту ще дет льно не проводили.

ме тому об'єктом н шого дослідження обр но один з н йст ріших гідротер певтичних курортів ьвівської обл. - сів, предметом - ретроспективно-рекре ційний н ліз специфіки його функціонув ння. вд ння дослідження - ілюстр ція н прикл ді конкретного курорту ресурсно- й історико-геогр фічних передумов розвитку рекре ції н території ьвівської обл.

сів у ст. - це один з н йприн дніших для тогоч сних львів'ян курортів личини. істечко, з снов не 1615 р. руським воєводою в ном ниловичем, ще н прикінці XVII ст. просл вилося як осередок ристокр тичної рекре ції під покровительством короля н обеського, який любив відпочив ти тут т полюв ти в н вколишніх ліс х. спр вжньої курортної сл ви сів н був у другій половині ст., коли поз містом пост в гідротер певтичний з кл д для лікув ння низки хронічних 3 хворюв нь.

(C) утинський ., 2013 
урорт сів був розміщений у м льовничій долині, яку з трьох боків оточув ли гори, вкриті з повідними пр ліс ми. рогулянкові стежки вели н вершину гори ородисько, де, з перек з ми, у добу иївської усі існув ло укріплене поселення, н гору торожих , звідки відкрив ється неозор п нор м долини і п см ороняків, т , передусім, до овіяної н родними легенд ми вятої гори, з якої било джерело: його місцеве н селення н діляло чудодійними цілющими вл стивостями.

одерний курортний гідротер певтичний з кл д “сів” з кл дений гр фом т рженським 1869 р. н одному з острівців, утворених притокою річки хідний уг [2].

суміжних остров х було розбито 80-морговий курортний гідроп рк зі ст вом посередині. стрівці сполуч ли один з одним прогулянкові місточки. леї від гр фського п л цу т трьох корпусів для відпочив льників вели до ст ву з обл дн ним пляжем, льт нк ми і човновою ст нцією.

біч п л цу функціонув в рестор н для курортників зі спеці льно розробленим дієтичним меню. ещо д лі стояв двоповерховий корпус для гідротер певтичних процедур, обернений просторими вікн ми н південь. ерув в з кл дом гідротер певт

p нцішек едвей.

зр зком німецьких гідролік рень комплекс лікув льно-оздоровчих процедур у гідротер певтичному 3 кл ді “ сів” скл д вся з дозов ного прийому холодних і г рячих в нн у поєдн нні з гімн стикою і рухливим дозвіллям, фітоклім тооздоровчими теренкур ми у сосновому п рку т дієтичним х рчув нням [4, s. 113].

т ном н 1871 р. $з$ літній сезон у гідротер певтичному з кл ді “ сів” ст ціон рно оздоровлялися 96 осіб, з кільк попередніх років їхня кількість бул не менше 80 осіб [3, s. 7]. порядок більше серед курортників було одноденних відвідув чів т рекре нтів, розкв ртиров них поз меж ми з кл ду. сь як описує інтенсивність рекре ційних потоків н жегожевський: “...3 весни... ж до осені... той 3 куток мерехтить і роїться щор з новими н плив ми прибув ючих і від'їждж ючих гостей,

в місяцях липні і серпні, коли їхня кількість сяг є кульмін ції, є осередком, що сповнений життя і розвою. уп льні помешк ння з повнені вщерть, т к що пізніше прибулі розкв ртировуються у містечку й н передмісті. им ч сом розпочин ються гучні фестини і з б ви, вечори т нців і концерти, прогулянки у ідгірці т інші околиці... рк, з звич й, призн чений для вольготних і рухливих тов риських ігор, щонеділі і н свят роїться людьми” [3, s. 5-6].

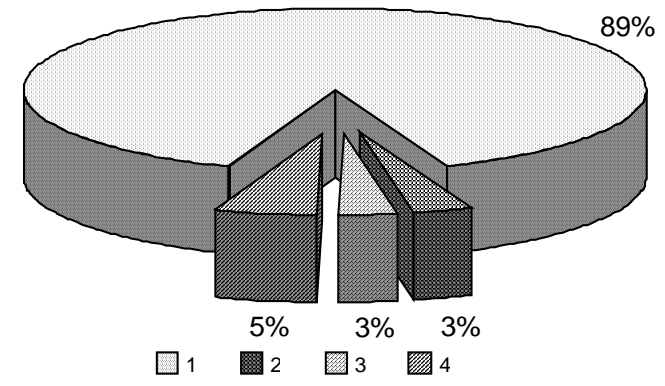

ис. 1. труктур рекре нтів, які ст ціон рно оздоровлялися н курорті в літньому сезоні 1871 p.

(скл дено 3 д ними [3, s. 7-8]): 1-зі хідної

личини; 2 - із хідної личини; 3 - з інших регіонів встро- горщини; 4-3 олині. еогр фія рекре ційних потоків у сів тр диційн для тогоч сних м лих курортів хідної личини, у яких, з звич й, кр яни ст новили пон д дві третини курортної публіки (рис. 1).

обсяг ми рекре ційних потоків у 70-ті роки ст. курорт сів не поступ вся т ким відомим 3 хідноукр їнським курорт м, як оршин, елятин, осів i уркут. ля інтенсифік ції потоку рекре нтів дирекція курорту регулярно проводил ктивні рекл мні к мп нії (див. рис. 2). 


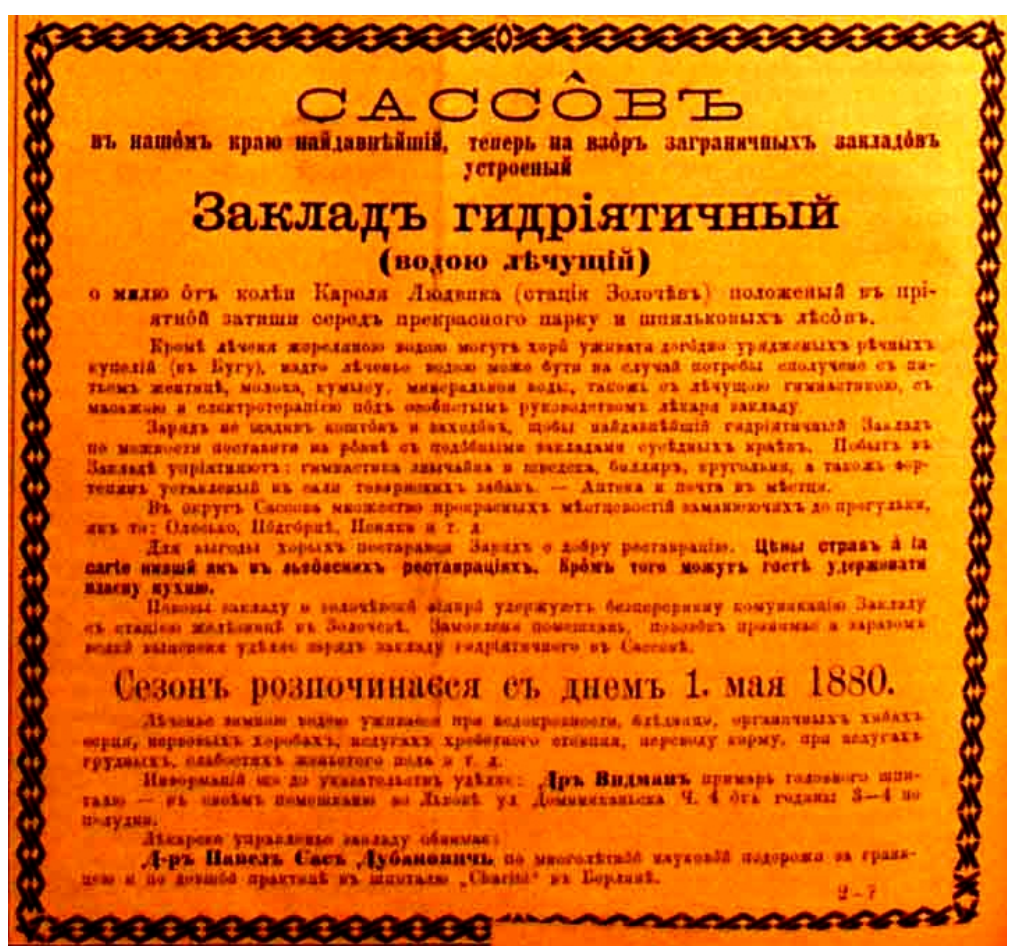

ис. 2. ипове рекл мно-інформ ційне оголошення про оздоровчі можливості курорту н друков не у г зеті “ іло” з 26 квітня 1880 p.

опри інтенсивний розвиток торгівлі т ф бричного виробництв п перу, н прикінці -н поч тку ст. сів ктивно розбудовув в інфр структуру для подорожніх. ньому функціонув ло близько 70 кр мниць, 6 г то шинків, $з$ їжджих дворів, бул і к в'ярня. ечор ми н центр льних вулицях світили г сові ліхт рі, для гостей, які прибули н курорт, проте зупинилися н постій у місті, до гідротер певтичного з кл ду упродовж цілого дня курсув ли кінні екіп жі [5-7].

тім, 31880 р. в умов х дед лі більшого конкурентного тиску з боку г лицьких б льнеологічних курортів сів, де не було вл сного джерел мінер льних вод, втр тив більше половини своїх клієнтів і поч в з неп д ти. 1889-1894 рр. гідротер певтичний корпус стояв з чинений, 3 кл д функціонув в винятково як озерно-лісове літнисько для незн чної кількості рекре нтів [5, s. 409].

1895 р. проведено повну реконструкцію т відновлено функціонув ння гідрооздоровниці. орпус "розділено н дв відділи - чоловічий т жіночий - і в кожному з них розт шов ні окремі к бінети для прийому в нн зі штучними мінер льними вод ми, з джерельними вод ми т душовими" [5, s. 409]. уло т кож відкрито к бінети лікув льного м с жу т електрофізіотер пії. урортник ми з йм лися лік рі 3 нко, льсбург і уб нович.

сів профільов но для лікув ння нервових і серцево-судинних 3 хворюв нь т легеневих хвороб. екре ційн місткість 3 кл ду ст новил 80 ліжко-місць (у центр льному корпусі т ще чотирьох будинк х). т ном н ост нні літні сезони кінця ст. 
сів відвідув ло близько двох сотень рекре нтів, з них близько сотні під ч с проходження курсу процедур ст ціон рно прожив ли в оздоровниці.

поч тку ст. курортом опікув вся відомий г лицький курортолог икол оросевич. гр фському п л ці в цей період бул дирекція курорту т н йдорожчі покої для ристокр тичних відвідув чів. ентр льний б льний 3 л п л цу використовув ли для орг ніз ції культурного дозвілля курортної публіки. творчі вечори т концерти, які відбув лися в п л цовій з лі, з'їждж л ся вся дрібн шляхт і єврейські кр м рі 3 олочев й сусідніх містечок. ум рн ж кількість рекре нтів у сезони 1911-1913 рр. сяг л пон д три сотні осіб.

од льший розвиток успішного й доволі популярного курорту перерв л ерш світов війн . ісля війни курорт не відновлюв ли.

тже, у процесі еволюційного поступу курорт сів пройшов через повний цикл розвитку і є типовим прикл дом встро-угорського ет пу територі льної орг ніз ції мережі "м лих" прив тних курортів личини в ст. ивчення досвіду орг ніз ції т кого типу “м лих" курортних центрів н під'їзних шлях х до ьвов д сть змогу сформув ти коректне н укове підгрунтя для прогнозно-геогр фічного моделюв ння потенці лу й векторів суч сної розбудови рекре ційно-курортної сфери ьвівщини н з с д х екозорієнтов ного ст лого розвитку.

1. утинський . . стосув ння теорії “життєвого циклу територі льної рекре ційної системи” для "м лих" курортних центрів кр їни / . . утинський // кономічн т соці льн геогр фія. - 2013. - ип. 2 (67). - . 177-191.

2. Ebers H. Sassów, zakład wodoleczniczy w Galicyi pod Złoczowem w r. 1883 / H. Ebers. - Lwów : T-wo Pedagog., 1883. - 12 s.

3. GrzegorzewskiJ. Sassów i jego okolice / Odb. z "Gazety Narodowej” / J. Grzegorzewski. - Lwów : T-wo Pedagog. Złoczowskie, 1872. - 32 s.

4. Heksch A.F. Führer durch die Ungarischen Ostkarpathen, Galizien, Bukowina und Rumänien / A. F. Heksch, W. Kowszewicz. - Wien; Leipzig : Hartleben Verlag, 1882. $248 \mathrm{~s}$

5. Korczyński L. Zarys balneoterapii i balneografii krajowej dla u ytku lekarzy i uczniów / L. Korczyński. - Kraków, 1900. - 490 s.

6. Orłowicz M. Przewodnik po zdrojowiskach, letniskach i stacyach turystycznych Galicyi / M. Orłowicz, K. Praschil. - Lwów : Grafil, 1916. - 310 s.

7. Reichman Fr.S. Sassów / Zdrojowiska krajowe / Fr. S. Reichman // Ilustrowany skorowidz stołecznego miasta Lwowa z okazyi powszechnej Wystawy krajowej roku 1894. - Lwów, 1894. - S. 63.

m ття: н дійщл до ред кцї̈ 24.07.2013

доопр иьов н 16.08.2013

прийнят до друку 10.10.2013 


\section{SASIV RESORT IN LVIV REGION: \\ HISTORICAL AND GEOGRAPHICAL PECULIARITIES OF FUNCTIONING IN THE NINETEENTH-EARLY TWENTIETH CENTURY}

\section{Mykhailo Rutynskiy}

Ivan Franko National University of Lviv,

P. Doroshenko Str., 41, UA-79000 Lviv, Ukraine

Resource and recreational potential of the historical and geographical features of the evolution of Sasiv are characterized. Based on the analysis of spatial and temporal dynamics the role and place of resort in the territorial recreational system of Lviv region in late XIX-early XX centuries were evaluated.

Key words: resort, Sasiv, institution hydrotherapeutic, periods of development, factors and dynamics of development.

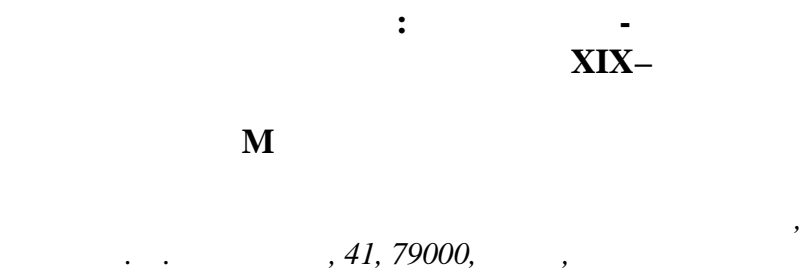

роведено историко-геогр фическое исследов ние рекре ционно-инфр структурного потенци л курорт сов в период его функциониров ния. основ нии н лиз процессов простр нственно-временной дин мики д но оценку зн чения и мест здр вницы в территори льной рекре ционной системе ьвовщины конц $\mathrm{XIX-н} \mathrm{ч} \mathrm{л} \mathrm{вв.}$

лючевые слов : курорт, сов, гидротер певтическое з ведение, периодиз ция р звития, ф кторы и дин мик р звития. 